Данилюк Ю. М., студентка IV курсу

Інституту філології

Київського університету імені Бориса Грінченка
Danyliuk Yuliia,

IV year student, Institute of Philology

of Borys Grinchenko Kyiv University

удК 82-1: 81’38+655

\author{
ЖАНРИ НАУКОВОГО СТИЛЮ: \\ СТРУКТУРА, ЛЕКСИКА, СИНТАКСИС
}

\title{
GENRES OF SCIENTIFIC STYLE: STRUCTURE, VOCABULARY AND SYNTAX
}

\begin{abstract}
Анотація. У статті названі та описані жанри наукового стилю. Авторка роботи з’ясовує особливості архітектоніки наукових текстів, вивчає їх лексичні і синтаксичні особливості.

Матеріал до статті зібрано й упорядковано у межах дисиилліни «Основи редакторської майстерності», змістовий модуль «Редагування наукових текстів» (викладач - доцент кафедри видавничої справи Інституту журналістики Верниигора Н. М.).

Ключові слова: науковий стиль, жанри наукового стилю, лексичний рівень наукового тексту, синтаксичний рівень наукового тексту.

Abstract. The article deals with the genres of scientific style, their peculiarities, in particular, the peculiarities of its lexical and syntactic levels.

The research was carried out within the framework of study of the discipline "Fundamentals of Editorial Skills" (the Lecturer-Vernyhora N. M., Associate Professor of Publishing Department).

Keywords: scientific style, lexical level, syntactic level, subcategories, genres.
\end{abstract}

B ступ. Редактор повинен вміти опрацьовувати тексти наукового стилю, знати його особливості, розрізняти підстилі та жанри цього стилю, добре знатися на структурі наукового тексту. Саме цим зумовлена актуальність вивчення теми. Водночас у науковому повідомленні описані синтаксичний та лексичний рівні наукового стилю, які, хоч і є добре вивченими, проте потребують деяких уточнень.

Дослідження за темою. Науковий стиль добре описаний $з$ філологічної точки зору. Тут можна назвати праці таких знаних науковців і педагогів, як: А. П. Коваль [1], О. Д. Пономарів [2], М. С. Зарицький [3].

Нині над вивченням теми працюють О. М. Семиног [4], Л. І. Мацько [5; 6], Л. В. Кравець [5], Г. О. Денискіна [6], К. Городенська [7]. 3 редакційно-видавничої точки зору проблематику зазначеної теми вивчення до певної міри описано в публікаціях Н. М. Вернигори [8; 9]. Про особливості наукового тексту йдеться також у працях Н. В. Зелінської, В. В. Різуна, А. І. Мамалиги, М. Д. Феллера та ін. Втім, для якісної редакторської роботи з науковим текстом у сучасний період входження української науки в світовий контекст, тема все ще потребує нових досліджень.
Мета пропонованого дослідження - вивчити жанри наукового стилю, з'ясувати їх структуру. Для реалізації зазначеної мети визначено такий перелік завдань:

- з'ясувати основні ознаки наукового стилю;

- назвати і охарактеризувати жанри наукового стилю;

- описати проблеми термінології в наукових текстах;

- назвати сталі ознаки лексичного і синтаксичного рівнів наукового твору.

Методи дослідження. У процесі виконання поставлених завдань було застосовано загальнонаукові методи аналізу, синтезу та узагальнення, а також описовий та історичний.

Результати й обговорення. Загалом виникнення i розвиток наукового стилю пов'язані 3 еволюцією різних галузей наукових знань, різноманітних сфер діяльності людини. Спочатку стиль наукового викладу був близький до художньої оповіді. Наприклад, наукові праці Піфагора, Платона і Лукреція відрізнялися особливим, емоційним сприйняттям явищ. Відділення наукового стилю від художнього відбулося в Олександрійський період, коли в грецькій мові, яка

(С) Данилюк Ю. М., 2017 
поширилася на весь тодішній культурний світ, почала формуватися стійка термінологія [1]. Згодом їі доповнила латинь - інтернаціональна наукова мова європейського середньовіччя. В епоху Відродження вчені прагнули до стислості і точності опису, вільного від емоційно-художніх елементів викладу, які суперечили абстрактно-логічному відображенню природи. Відомо, що занадто «художній» характер розповіді Галілея дратував Кеплера. Те, що стиль наукових доказів Галілея надмірно «белетризований», підтверджував і Декарт. А взірцем наукової мови у подальшому став чіткий логічний виклад Ньютона.

У науковому стилі розрізняють певні різновиди (підстилі): власне науковий, навчально-науковий та науково-популярний. Урешті-решт стиль наукової роботи визначається з урахуванням насамперед іiі змісту та мети - за можливості точно і повно пояснити факти навколишньої дійсності, показати причинно-наслідкові зв'язки між явищами, виявити закономірності історичного розвитку тощо.

У галузі науки і навчально-наукової діяльності обмін інформацією відбувається саме за допомогою текстів у науковому стилі. Цей стиль належить до книжкових стилів української літературної мови, що мають спільні умови функціонування і схожі мовні особливості, такі як попереднє обдумування висловлювання, монологічний характер мовлення, строгий відбір мовних засобів, прагнення до нормованої мови.

За допомогою наукового стилю реалізується мовна функція повідомлення. Тексти, написані цим стилем, містять наукову інформацію, яку треба донести до різних верств суспільства. 3 його допомогою доводять теорії, обгрунтовують гіпотези, повідомляють наслідки досліджень, пояснюють явища 3 наукової точки зору, здійснюють систематичний виклад певних знань тощо.

Основні ознаки наукового стилю:

- ясність (зрозумілість) і предметність тлумачень;

- логічна послідовність та доказовість викладу;

- об’єктивний аналіз;

- точність і лаконічність висловлювань;

- аргументація і переконливість тверджень;

- детальні висновки.

Виокремлюють такі різновиди (niдcтилi) наукового стилю:

- власне-науковий;

- науково-популярний;

- науково-навчальний.

Зберігаючи основні ознаки стилю, кожний підстиль характеризується певними особливостями використання мовних засобів. Наприклад, власне науковий передбачає використання інтернаціональних загальнонаукових термінів; науково-популярнии елементів художнього мовлення (епітетів, порівнянь, метафор) з метою зацікавлення читача; науково-на- вчальний підстиль характеризується доступністю викладу інформації, спрощеністю системи доведень, програмністю викладу матеріалу, спрямованою на активізацію мислення учня, поступовим, послідовним уведенням термінологічної лексики.

Призначення власне наукового підстилю - насамперед об'єктивувати наукові відомості і кінцеві результати аналітико-синтетичного перероблення даних, а основна функція - пояснення наукової ідеї. У межах власне наукового підстилю теоретики виокремлюють також науково-інформативний різновид 3 жанрами реферату, анотації, резюме та огляду, а також науково-довідковий (довідники, словники, каталоги).

У полі зору нашого тематичного дослідження перебувають жанри власне наукового підстилю, до яких належать:

- монографія;

- стаття;

- дисертація;

- автореферат дисертації;

- наукова доповідь;

- тези наукової доповіді.

Монографія - наукова праця (книга), в якій досліджується одна проблема, обмежене коло питань. Автор пропонує власну наукову гіпотезу чи концепцію вирішення важливої наукової проблеми. У монографії обов'язково мають бути теоретичні розділи, висновки і список наукової літератури [1].

Cтаття - наукова праця невеликого розміру, присвячена певній темі і розрахована на обізнаних у цій темі фахівців. Наукові статті бувають повідомлювальними (інформують про нові результати дослідження), оглядовими (аналіз подій, явищ тощо, їх зіставлення, виявлення найважливіших напрямів у розвитку науки), аналітичними (всебічний аналіз репрезентативних фактів, що сприяє вирішенню наукової проблеми), дискусійними (про спірні питання) [1].

Дисертація - наукова праця, підготовлена для прилюдного захисту на здобуття вченого ступеня. У дисертаційних дослідженнях відкривають нові напрями в науці, започатковують досі невідомі підходи до вирішення складної проблеми, вивчають ще невідоме або з'ясовують питання, які забезпечують подальший розвиток певного напряму чи цілої галузі [1].

Автореферат дисертаиї - стислий виклад кандидатської та докторської дисертації, який виконується після її фактичного завершення та розсилається відповідно до спеціальних списків розсилки у спеціалізовані наукові організації з метою апробації та отримання відгуків на автореферат [2].

Наукова доповідь - жанр наукового стилю, що інформує про наукові досягнення, відкриття та винаходи, про результати експериментів, узагальнює наукові дані. Ї̈̈ виголошують на науковій конференції, симпозіумі, семінарі тощо [2].

Integrated communications, 201\% 
Тези є одним із найстійкіших жанрів. Вони мають нормативну змістово-композиційну структуру, в якій виокремлюють преамбулу, основне теоретичне положення та завершальну тезу (висновок). Чітке логічне членування змісту тез підкреслюється рубрикацією, а в деяких випадках - і виділенням абзаців під однією рубрикою [2].

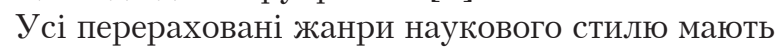
основну особливість - точне й однозначне висловлення наукових думок.

Лексичний рівень наукового стилю. Побічний, узагальнений характер наукового тексту проявляється на лексичному рівні в тому, що в ньому широко вживаються слова з абстрактним значенням. Навіть слова побутового характеру набувають у такому тексті узагальненого, часто термінологічного значення.

Термінологія становить основу наукового тексту. Вона втілюе високу точність мови, адже термін повинен однозначно трактувати поняття в конкретній галузі знань або професійної діяльності. Формування термінології, своєю чергою, є важливою умовою відтворення наукової мови. Використання термінів забезпечує взаєморозуміння фахівців на міжнаціональному і національному рівнях, а також сумісність нормативних і законодавчих актів.

Характерною ознакою наукового стилю $є$ його висока насиченість термінами. При цьому частка термінів порівняно із загальновживаною лексикою неоднакова в різних жанрах наукової мови. Важливо дати правильне, логічне визначення понять, що вводяться термінами, адже неправильно вжитий або незрозумілий термін може дезінформувати читача.

У суто науковому (академічному) стилі терміни не завжди пояснюються. Тим часом у наукових творах для широкої аудиторії (як і в навчальній літературі) зазвичай подається їх чітке визначення, наприклад: «Просодика - це загальна назва таких ритміко-інтонаційних сторін мови, як висота, гучність голосового тону, тембр голосу, сила наголосу». Терміни можуть пояснюватися через синоніми або етимологічні довідки (пояснення походження терміна). Їх визначення подається в дужках, у виносках.

Синтаксичний рівень наукового стилю. Синтаксичні особливості наукового стилю (побудова словосполучень і речень) виявляються доволі послідовно і відображають зв'язок з мисленням. Синтаксичні конструкції здебільшого загальновживані, нейтральні.

Наприклад, для наукового стилю характерні словосполучення іменників, в яких у функції визначення виступає родовий відмінок імені, часто 3 прийменником для (обмін речовин, коробка передач, прилад для монтажу). Імена прикметників у ролі визначення також широко вживаються в термінологічному значенні: голосні й приголосні звуки, кримінальний кодекс, умовні рефлекси тощо.
Для наукового стилю типовим є вживання іменного присудка (а не дієслівного), що сприяе створенню іменного характеру наукового стилю. Найчастіше іменні присудки трапляються у визначеннях і міркуваннях. Широковживаними в науковому стилі є іменні складові присудки з короткими дієприкметниками, приміром, «може бути використаний» .

Специфіка наукового стилю також проявляється на рівні речення. Оскільки логічність - одна 3 основних стильових ознак такого тексту, для його синтаксису характерні структури, що насамперед виражають суто понятійний зміст. Основною з них у багатьох мовах є повнозмістовне розповідне речення 3 нейтральним (зі стильової точки зору) лексичним наповненням, з логічно правильним (нормативним), прямим порядком слів.

Простих речень у науковій мові стільки ж, скільки складних. Середній розмір простого речення - близько 20 слів, складного - близько 30. Серед складнопідрядних переважають речення з одним підрядним.

Питальні речення виконують у науковій мові специфічні функції, пов'язані з прагненням привернути увагу до розповіді. Таку саму незвичайну роль виконують і спонукальні (для вираження допущень і пропозицій) речення.

Для наукового стилю характерне широке поширення безособових речень різних типів, тому що в сучасній науковій мові особиста манера викладу поступилася місцем безособовій, що обумовлено прагненням до об'єктивної узагальненості й абстрагованості. При цьому часто використовуються пасивні конструкції, відсутня вказівка на виробника дії.

У наукових текстах з'ясовуються причинно-наслідкові зв'язки між явищами, тому зазвичай трапляються складні речення зі складними сурядними й підрядними сполучниками та сполучні слова, такі як: незважаючи на те що, з огляду на те що, тому що, внаслідок того що, тоді як, між тим як, у той час як та ін. Найбільш продуктивні в наукових текстах складнопідрядні речення з підрядними причини, часу, умовно-наслідковими, з'ясувальними.

Специфічною ознакою наукового стилю є вживання складнопідрядних речень, де висловлюється зіставлення будь-яких явищ, та однорідних членів речення, які позначають логічно однорідні поняття.

У науковій мові також використовується група вставних слів і словосполучень, що містять вказівку на те, ким висловлена та або та думка, кому належить те чи те висловлювання, яке джерело повідомлення (на нашу думку, на переконання, за відомостями, за повідомленням, з точки зору, відповідно до гіпотези, визначення та ін.)

Для таких текстів характерна композиційна зв'язаність окремих частин, яка досягається за допомогою сполучних слів чи груп слів, що відобра-

Інтегровані комунікації, 201\% 
жають етапи логічного викладу і є засобом зв'язку думок у процесі логічного міркування [4].

Висновки. Основне завдання наукового стилю гранично ясно і точно донести до читача інформацію. А це найкращим чином можна зробити без використання емоційних засобів.

Сфера застосування наукового стилю доволі широка. Це один із стилів, який нині чинить потужний i різнобічний вплив на літературну мову, адже завдяки науково-технічній революції величезна кількість термінів перейшли у загальне вживання. Комп'ютер, дисплей, екологія, стратосфера, сонячний вітер - ці та багато інших термінів перекочували зі сторінок спеціальних видань у повсякденний побут. Якщо раніше тлумачні словники складалися на основі мови художньої літератури і меншою мірою публіцистики, то зараз опис розвинених мов світу неможливо уявити без наукового стилю.

Його інтенсивний розвиток сприяв формуванню численних жанрів, таких як: стаття, монографія, дисертація, автореферат дисертації, наукова доповідь, тези та ін. Кожному жанрові притаманні свої індивідуально-стильові ознаки, однак вони не порушують єдності науково-технічного стилю, наслідуючи його загальні ознаки й особливості.

Однак, через швидкий розвиток суспільства, стрімкий прогрес науки і техніки виникає потреба у постійному вдосконаленні спеціальної мови, найкращим чином пристосованої до висловлення і передавання наукового знання.

\section{Список літератури}

1. Коваль А. П. Практична стилістика української мови : навч. посіб. / А. П. Коваль. - Київ : Рад. шк., 1987.

2. Пономарів О. Д. Стилістика сучасної української мови : підручник / О. Д. Пономарів. - Київ : Либідь, 1992.

3. Зарицький М. С. Стилістика сучасної української мови : навч.-метод. посіб. / М. С. Зарицький. - Київ : ВКФ «Сатсанга», 1999. - 88 с

4. Семеног О. М. Культура наукової української мови : навч. посіб. / О. М. Семеног. - Київ : Академія, 2010. - 215 c.

5. Мацько Л. І. Культура української фахової мови : навч. посіб. / Л. І. Мацько, Л. В. Кравець. - Київ : ВЦ «Академія», 2007. - 360 с.

6. Мацько Л. І. Українська наукова мова (теорія і практика) : навч. посіб. / Л. І. Мацько, Г. О. Денис- кіна. - Тернопіль : Підручники і посібники, 2011. $272 \mathrm{c}$.

7. Городенська К. Синтаксична специфіка української наукової мови / Катерина Городенська / / Українська термінологія і сучасність : зб. наук. пр. - Київ : КНЕУ, 2001. - Вип. IV. - С. 11-14.

8. Вернигора Н. М. Написання сучасної наукової статті. Методичні рекомендації / Н. М. Вернигора ; Київ. ун-т ім. Бориса Грінченка, Гуманітарний ін-т. Київ : Білий Тигр, 2015. - 28 с.

9. Вернигора Н. М. Жанри наукової періодики (Методичні рекомендації щодо формування структури $\mathrm{i}$ рубрикації текстів) // І Інтегровані комунікації : наук. журн. / Ін-т журналістики Київ. ун-ту ім. Бориса Грінченка. - Київ, 2016. - С. 46-52.

10. Культура фахового мовлення : навч. посіб. / за ред. Н. Д. Бабич. - Чернівці : Книги - XXI, 2006. - 496 с.

\section{Reference list}

1. Koval, A. P. (1987), Practical Stylistics of the Ukrainian: a Textbook, Radianska Shkola, Kyiv.

2. Ponomariv, O. D. (1992), Stylistics of the modern Ukrainian: a Manual, Lybid, Kyiv.

3. Zarytskyi, M. S. (1999), Stylistics of the modern Ukrainian: a Textbook, VKF «Satsanha», Kyiv, 88 p.

4. Semenoh, O. M. (2010), Culture of the scientific Ukrainian: a Textbook, Akademiia, Kyiv, 215 p.

5. Matsko, L. I. \& Kravets, L. V. (2007), Culture of Ukrainian Professional Language: a Textbook, VTs "Akademiia", Kyiv, 360 p.

6. Matsko, L. I. \& Deniskina, G. O. (2011), Ukrainian Scientific Language (Theory and Practice): a Textbook, Pidruchnyky i posibnyky, Ternopil, 272 p.

7. Horodenska, K. (2001), "Syntactic specificity of the Ukrainian scientific language", Ukrainska Terminolohiia $i$ Suchasnist: Zbirnyk Nauk. Prats [Ukrainian Terminology and Contemporaneity: Collection of Scietific Works], no. IV, pp. 11-14, KNEU, Kyiv, 368 p.

8. Vernyhora, N. M. (2015), Creation of the Modern Scientific Article. Methodical Guidelines: Borys Grinchenko Kyiv University, Humanitarian Institute, Bilyi Tyhr, Kyiv, 28 p.

9. Vernyhora, N. M. (2016), Genres of Scientific Periodicals. Methodical Guidelines: Integrated Communications: Scientific Journal, Institute of Journalism of Borys Grinchenko Kyiv University, Kyiv, P. 46-52.

10. Babych, N. D. (Ed.) (2006), Culture of Professional Broadcasting: a Textbook, Knyhy -XXI, Chernivtsi, 496 p.

Подано до редакиї 25. 01. 2017 р.

Данилюк Ю. Н., студентка

Института филологии

Киевского университета имени Бориса Гринченко

\title{
ЖАНРЫ НАУЧНОГО СТИЛЯ: СТРУКТУРА, ЛЕКСИКА, СИНТАКСИС
}

\begin{abstract}
Аннотация. В статье названы и описаны жанры научного стиля. Автор работы разбясняет особенности архитектоники научных текстов, изучает их лексические и синтаксические особенности.

Материал для статьи собран и упорядочен в рамках дисциплины «Основы редакторского мастерства: Редактирование научных текстов».
\end{abstract}

Ключевые слова: научный стиль, жанры научного стиля, лексический уровень научного текста, синтаксический уровень научного текста. 